\title{
Gan-Lu-Yin Inhibits Proliferation and Migration of Murine WEHI-3 Leukemia Cells and Tumor Growth in BALB/C Allograft Tumor Model
}

\author{
Fon-Chang Liu,, ${ }^{1,2}$ Chun-Hsu Pan,, Ming-Tsung Lai,, ${ }^{3,4}$ Shu-Jen Chang,, \\ Jing-Gung Chung, ${ }^{5}$ and Chieh-Hsi $\mathrm{Wu}^{1}$ \\ ${ }^{1}$ School of Pharmacy, China Medical University, 91 Hsueh-Shih Road, Taichung 40402, Taiwan \\ ${ }^{2}$ Department of Pharmacy, Da Chien General Hospital, Miaoli 36052, Taiwan \\ ${ }^{3}$ Department of Pathology, Chung Shan Medical University, Taichung 40201, Taiwan \\ ${ }^{4}$ Department of Pathology, Chung Shan Medical University Hospital, Taichung 40201, Taiwan \\ ${ }^{5}$ Graduate Institute of Biological Science and Technology, China Medical University, Taichung 40402, Taiwan
}

Correspondence should be addressed to Chieh-Hsi Wu; chhswu@mail.cmu.edu.tw

Received 21 November 2012; Accepted 4 February 2013

Academic Editor: Evan Paul Cherniack

Copyright (C) 2013 Fon-Chang Liu et al. This is an open access article distributed under the Creative Commons Attribution License, which permits unrestricted use, distribution, and reproduction in any medium, provided the original work is properly cited.

\begin{abstract}
The aim of this study was to explore the antitumor effect of Gan-Lu-Yin (GLY), a traditional Chinese herbal formula, on leukemia. Ethanolic extract of GLY was applied to evaluate its regulatory mechanisms in proliferation, migration, and differentiation of WEHI3 leukemic cells as well as antitumor effect on BALB/c mice model. The results showed that GLY markedly reduced cell proliferation and migration with induced differentiation of WEHI-3 cells. The expression level of phosphorylated FAK, Akt, ERK1/2, and Rb was decreased p21 expression while level was increased in WEHI-3 treated with GLY. The results of cell cycle analysis revealed that GLY treatment could markedly induce G1 phase arrest and decrease cell population in S phase. Moreover, experimental results demonstrated that GLY decreased the protein expression and enzyme activity of MMP-2 and MMP-9. GLY treatment also reduced WEHI-3 leukemic infiltration in liver and spleen and tumor growth in animal model. Accordingly, GLY demonstrated an inhibitory effect on tumor growth with a regulatory mechanism partially through inhibiting FAK, Akt, and ERK expression in WEHI-3 cells. GLY may provide a promising antileukemic approach in the clinical application.
\end{abstract}

\section{Introduction}

In clinical, acute myeloid leukemia (AML), long-term survival is poor $[1,2]$. Leukemia cancer is a highly complex, multitarget disease. Due to the defective cell signaling pathways, these cancer cells might alter their normal cycles of proliferation, transcription, growth, migration, differentiation, and death. The cells have the ability to avoid apoptosis and to proliferate in an uncontrolled manner leading to development of cancer. Arsenic trioxide (ATO) and all-trans retinoic acid (ATRA) have good clinical efficacy in treating the newly diagnosed and relapsed acute promyelocytic leukemia (APL, a subtype of AML) and AML [3]. Although Glasow et al. indicated that ATRA signaling plays a critical role in myelomonocytic differentiation [4], thus an important target for anti-AML therapy, several limitations constrained the use of ATRA in the treatment of AML. Long-term treatment of ATRA and ATO resulted in serious side effects including hypertension [5], interstitial pulmonary infiltrates, pleural and pericardial effusion, dyspnea, episodic hypotension, and acute renal failure [6]. Due to the drawbacks in treating AML, a new therapeutic agent with greater efficacy and fewer side effects for the treatment of this disease is urgently needed.

Myeloblast cells (immature blood cells) possess two major functions to maintain normal physiological condition. Firstly, these cells are prone to cell proliferation to maintain the normal white blood cell number. Secondly, a cell can be differentiated to some mature cell with a specific function (e.g., white blood cell). Cell proliferation is usually counteracting cell differentiation. Therefore the balance 
between proliferation and differentiation of hematopoietic cell becomes very important [7]. It is generally believed that the proliferation, differentiation, and migration of leukemia cells were involved in the development of tumor growth and invasion. Therefore, modulation of leukemia cell growth, differentiation, and migration has important therapeutic implications.

Many Chinese herbal medicines have been reported to have antileukemia cancer ability [8]. GLY consists of Rehmannia glutinosa, Liriope spicata (Thunb.) Lour, Eriobotrya japonica (Thunb.) Lindl., Citrus sinensis Osbeck, Glycyrrhiza uralensis Fisch, Artemisia capillaris Thunb, Dendrobium nobile Lindl., and Scutellaria baicalensis Georgi. In clinical practice, GLY has been routinely used in oral ulcer or swollen gums. This formula has been widely used to expel heat, to remove the dampness, to resolve inflammation, and to clean the blood according to the traditional Chinese medicinal prescriptions, Tai Ping Hui Min He Ji Ju Fang. Recently, we discovered that GLY has antiangiogenesis effect [9], and several other studies also showed that some single ingredient within GLY formula has biological effect on cell differentiation $[10,11]$. To date, the effects of GLY on AML treatment are still unclear. Thereby, the present study was designed to evaluate the antitumor activities of GLY on BALB/c mice grafted with WEHI-3 cells and to investigate its inhibitory mechanisms in vitro. This study will help us to elucidate whether GLY treatment has potential to be an effective pharmacological reagent to treat leukemia cancer.

\section{Materials and Methods}

2.1. Materials. The ingredients of GLY were provided from Pharmacy Department of China Medical University Hospital, Taichung, Taiwan. Fetal bovine serum (FBS), penicillin G, and streptomycin were obtained from Invitrogen (Carlsbad, CA, USA). Primary antibodies against p-ERK1/2 (sc7383) and $\mathrm{p}-\mathrm{Rb}$ (sc-16670) were purchased from Santa Cruz Biotechnology (Santa Cruz, CA, USA). Antibodies against p-Akt (ab28821), p21 (ab379601), MMP-9 (ab58803), and $\beta$ actin (ab8226) were from Abcam (Cambridge, MA, USA). Phosphorylated-FAK (p-FAK, 8556) and MMP-2 (4022) were purchased from Cell Signaling (Beverly, MA, USA). Secondary antibodies conjugated with horseradish peroxidase were obtained from Santa Cruz Biotechnology. All other reagents were purchased from Sigma-Aldrich (Louis, MO, USA).

\subsection{Preparation of GLY Extract. The ingredients of GLY} formula were equally weighed (about $1 \mathrm{~kg}$ ) and soaked in 10 liters of $50 \%$ ethanol solution (extractive solvent) for 3 days at room temperature. The solid residue of the above soaked herbs was filtered and discarded through a Buchner funnel lined with Whatman filter paper and the filtrate was concentrated to paste by vacuum distillation by using rotary evaporator (N-11, EYELA, Tokyo, Japan) and vacuum controller (VC-760, TAKARA, Tokyo, Japan) to maintain the desired pressure and temperature at $35^{\circ} \mathrm{C}$ with $40 \mathrm{~mm} \mathrm{Hg}$. The various concentrations of GLY were further diluted with Milli-Q water for the further use.
2.3. Cell Culture. WEHI-3 cells were purchased from Food Industry Research and Development Institute (Hsinchu, Taiwan). The cells were seeded on $75 \mathrm{~cm}^{2}$ tissue culture flasks and culture condition as described previously [12].

2.4. Cell Viability Assay. Cell viability was determined by the previous study with minor modification [13]. Cells were seeded on 6 -well plates $\left(2 \times 10^{5}\right.$ cells/well $)$ and exposed to various concentration of GLY extract for $24 \mathrm{~h}$ in a total volume of $1 \mathrm{~mL}$ culture medium with $10 \%$ FBS supplement. After $24 \mathrm{~h}$ treatment, an aliquot of cells suspension was mixed with $0.4 \%$ trypan blue (GIBCO, USA) and to count cells with a hemocytometer while keeping a separate count of the blue cells. The cells that failed to exclude the dye were considered nonviable; therefore, the data is expressed as a percentage of viable cells.

2.5. Cell Cycle Analysis. Cells were seeded on 6-well plates $\left(2 \times 10^{5}\right.$ cells/well $)$ and exposed to various concentrations of GLY extract for $24 \mathrm{~h}$ in a total volume of $1 \mathrm{~mL}$ culture medium with $10 \%$ FBS supplement. After $24 \mathrm{~h}$ treatment with GLY, WHE-3 cells were harvested and washed with cold $1 \times$ PBS and then fixed with $70 \%$ ice-cold ethanol overnight. After ethanol was removed by centrifugation, pellets were resuspended in $500 \mu \mathrm{L}$ of DNA staining buffer $(4 \mu \mathrm{g} / \mathrm{mL}$ of propidium iodide, $1 \%(\mathrm{v} / \mathrm{v})$ Triton X-100, and $0.1 \mathrm{mg} / \mathrm{mL}$ of RNase A) and then incubated for $30 \mathrm{~min}$ at room temperature in the dark and followed by flow cytometry using FACSCanto (BD Biosciences, San Jose, CA, USA). Cell cycle profile was analyzed using ModFit LT Program (Verify Software House, Topsham, ME, USA).

2.6. Cell Differentiation Assay. Differentiation of WEHI-3 cells was assessed using the NBT (nitroblue tetrazolium) reduction test. The assay was carried out according to the method with a minor modification [14]. WEHI-3 cells were seeded on a 24 -well plate $\left(2 \times 10^{5}\right.$ cells/well $)$ and exposed to GLY for $48 \mathrm{~h}$ and then cells were harvested by centrifugation. After that, the experiment was performed by adding $200 \mu \mathrm{L}$ PBS containing $1 \mathrm{mg} / \mathrm{mL}$ NBT and $2 \mu \mathrm{g} / \mathrm{mL}$ phorbol myristate acetate solution at $37^{\circ} \mathrm{C}$ for $1 \mathrm{~h}$ in darkness. The mix solution was transferred to 96 -well plate then the cells were incubated for $1 \mathrm{~h}$ at $37^{\circ} \mathrm{C}$ in $5 \% \mathrm{CO}_{2}$. Following incubation, the medium was aspirated from the wells, cells washed twice with warm PBS, and then intracellular formazon crystals of pellets were dissolved by the addition of $100 \mu \mathrm{L}$ of DMSO to each well. The absorbance read at $570 \mathrm{~nm}$ on a spectrophotometer. The NBT-positive cells containing purple formazan deposits were identified using a light microscopy at $400 \mathrm{x}$ magnification.

2.7. Western Blot Analysis. The tumor tissues (50 mg) were homogenized in $250 \mu \mathrm{L}$ lysis buffer (iNtRON, Gyeonggi-do, Republic of Korea), and WEHI-3 cells $\left(1.6 \times 10^{6}\right.$ in $10 \mathrm{~cm}$ culture dish) were lysed with $0.07 \mathrm{~mL}$ lysis buffer. Tissue or cell lysate was incubated on ice for $30 \mathrm{~min}$ and insoluble components were removed by centrifugation at 13,000 rpm for $10 \mathrm{~min}$ at $4^{\circ} \mathrm{C}$. The supernatants were collected and their protein concentrations were determined by using the 
Bradford protein assay kit (Bio-Rad Laboratories, USA). Total proteins $(50 \mu \mathrm{g})$ were resolved in sodium dodecyl sulfatepolyacrylamide gel electrophoresis (SDS-PAGE) followed by blotting to PVDF (polyvinylidene fluoride) membrane (NEF1002001PK; Perkin Elmer, Boston, MA, USA). After total protein being successfully transferred on PVDF membrane, nonspecific binding sites were blocked by incubating membranes in $5 \%(\mathrm{w} / \mathrm{v})$ of nonfat milk dissolved in $1 \times$ PBS with $0.1 \%$ of Tween 20 (PBST buffer). Primary antibodies against p-FAK, p-Akt, p-ERK1/2, p-Rb, p21, MMP-2, and MMP-9 reconstituted in PBST buffer were added and incubated overnight at $4^{\circ} \mathrm{C}$. After being washed with PBST buffer, respective protein bands were visualized by using ECL reaction (Amersham, Arlington Height, IL, USA). The luminescence signal was acquired and analyzed by Fujifilm LAS-4000 system (San Leandro, CA, USA). The protein level was normalized to $\beta$-actin and presented as fold change to control group.

2.8. Gelatin Zymography. The test was performed as our previous study with minor modification [15]. WEHI-3 cells were seeded $\left(6 \times 10^{5}\right.$ cells/well) and incubated with GLY $(0,0.25$, 0.5 , and $1 \mathrm{mg} / \mathrm{mL}$ ) for $24 \mathrm{~h}$ under serum-free medium. The supernatant was collected by centrifugation at 10,000 rpm for 5 min. Thirty-two microliters of samples were mixed with eight microliters of $5 \mathrm{X}$ nonreducing loading buffer $(12.5 \%$ bromophenol blue, 10\% SDS, 0.5 M Tris-HCL pH = 6.8, 50\% glycerol) and then electrophoresed in $8 \%$ polyacrylamide gel with $0.1 \%(\mathrm{w} / \mathrm{v})$ gelatin. After that, the gel was washed twice ( $30 \mathrm{~min} /$ time) by $2.5 \%$ Triton $\mathrm{X}-100$, incubated with zymography reaction buffer $\left(1.54 \mathrm{mM} \mathrm{NaN}_{3}, 12.6 \mathrm{mM} \mathrm{CaCl}_{2}\right.$, $40 \mathrm{mM}$ Tris- $\mathrm{HCl}, \mathrm{pH} 8.0$ ) for an additional $18 \mathrm{~h}$ at $37^{\circ} \mathrm{C}$, and stained with coomassie blue R-250 (0.125\% coomassie blue R-250, 50\% methanol, 10\% acetic acid) and destained with destaining solution (methanol:acetic acid: water = $40: 10: 50, \mathrm{v} / \mathrm{v})$. Densitometric analysis of the gelatinasedigested (clear) bands was quantified by using Image J software (NIH, Bethesda, MD, USA).

2.9. Cell Migration Assay. The examination was tested as the method reported by Li et al. with minor modification [16]. The transwell cell culture chambers ( $5 \mu \mathrm{m}$ pore size, Corning Costar, Cambridge, MA) were applied to measure the migration effect of WEHI-3 cells treated with GLY. WEHI-3 cells resuspended in serum-free culture medium and placed in the upper chamber of the transwell insert $\left(1 \times 10^{6}\right.$ cells/well $)$ and incubated with GLY $(0,0.25,0.5$, and $1 \mathrm{mg} / \mathrm{mL})$ and culture medium (with $10 \%$ FBS as a chemoattractant) were added to the lower chamber. The plates were incubated in a humidified atmosphere with $95 \%$ air and $5 \% \mathrm{CO}_{2}$ at $37^{\circ} \mathrm{C}$ for $4 \mathrm{~h}$. The nonmigrated cells on the inner surface of the upper chamber were removed by wiping with a cotton swab, and migration cells on the outer surface of the upper chamber were fixed with $75 \%$ ethanol solution and stained with Giemsa solution. The migrated cells were determined using a light microscope (40x) and NIH Image software (Image J).

2.10. HPLC-ESI/MS Analysis of GLY Extract. The examination was performed according to our previous study with
TABLE 1: The HPLC separation conditions for identifying marked components within GLY.

\begin{tabular}{|c|c|c|c|c|}
\hline Compounds & Mobile phase & $\begin{array}{l}\text { Wavelength } \\
(\mathrm{nm})\end{array}$ & $\begin{array}{c}\mathrm{RT} \\
(\mathrm{min})\end{array}$ & $\begin{array}{c}\text { Contents } \\
\text { (mg/g of GLY) }\end{array}$ \\
\hline Naringin & $\begin{array}{c}\mathrm{ACN}: \mathrm{H}_{3} \mathrm{PO}_{4} \\
(0.11 \%, \mathrm{pH} 2.2)= \\
22: 78\end{array}$ & 280 & 10.83 & 13 \\
\hline Naringenin & $\begin{array}{c}\mathrm{ACN}: \mathrm{H}_{3} \mathrm{PO}_{4} \\
(0.11 \%, \mathrm{pH} 2.2)= \\
35: 65\end{array}$ & 288 & 8.58 & 0.32 \\
\hline Vanillin & $\begin{array}{c}\mathrm{ACN}: \mathrm{H}_{3} \mathrm{PO}_{4} \\
(0.0085 \%, \mathrm{pH} 3.0) \\
=30: 70\end{array}$ & 280 & 9.44 & 0.35 \\
\hline
\end{tabular}

Total volume of $10 \mu \mathrm{L}$ samples was loaded into the HPLC cartridge using a flow rate of $1.0 \mathrm{~mL} / \mathrm{min}$ to perform HPLC analysis. ACN: acetonitrile; RT: retention time.

minor modification [9]. The external standards and GLY extract were prepared as concentration of $100 \mu \mathrm{g} / \mathrm{mL}$ and $2 \mathrm{mg} / \mathrm{mL}$ in HPLC grade methanol, respectively. Before HPLC analysis, sample solutions were filtered through a $0.2 \mu \mathrm{m}$ filter. Total volume of $10 \mu \mathrm{L}$ sample was loaded into HPLC column to measure the relative content of naringin, naringenin, and vanillin within GLY extract according to the concentration of external standards. Separations were accomplished on LiChroCART 250-4 C18 HPLC-cartridge (5 $\mu \mathrm{m}$; Merck, Whitehouse Station, NJ, USA). The separation conditions of HPLC analysis for examined compounds were described in Table 1. According to the HPLC separation condition of standard compounds, three candidate fractions (collection period: retention time $\pm 5 \mathrm{~min}$ ) were harvested by HPLC system. These collected fractions were concentrated by evaporation and redissolved in methanol and then further examined by electrospray ionization-ion trap mass spectrometry (ESI-ion trap MS) system (HCT ultra-PTM Discovery system; Bruker Daltonics, Billerica, MA, USA) to identify the marked (or potential) compounds within GLY extract. Capillary voltage was $4000 \mathrm{~V}$, capillary exit offset $220 \mathrm{~V}$, skimmer potential $40 \mathrm{~V}$, and the trap drive value was 78 . Conventional ESI-MS/MS data were recorded using a scan range of 100$1000 \mathrm{~m} / \mathrm{z}$. Nebulizer (nitrogen) pressure was $10 \mathrm{psi}$, dry gas (nitrogen) flow $5 \mathrm{~L} / \mathrm{min}$, and dry temperature $300^{\circ} \mathrm{C}$.

2.11. WEHI-3 Allograft Tumor Model of BALB/c Mouse. The animal experiments were approved by the Institutional Animal Care and Use Committee of China Medical University (approval ID: 101-238-C). All animal care followed the institutional animal ethical guidelines of China Medical University. Twenty eight $\mathrm{BALB} / \mathrm{c}$ male mice (average 25-28 g; 8 weeks old) were obtained from Laboratory Animal Center, College of Medicine, National Taiwan University (Taipei, Taiwan). The mice were randomly divided into 4 groups ( $n=7 /$ group) and were kept on $12 \mathrm{~h}$ light/dark cycle at $25^{\circ} \mathrm{C}$. Group I (normal control group) was only given distilled deionized water (DDW). Group II (untreated group) was subcutaneously grafted with WEHI- 3 cells $\left(2 \times 10^{6}\right.$ cells in $100 \mu \mathrm{L})$. Group III was grafted with WEHI- 3 cells and then treated with GLY $(0.75 \mathrm{~g} / \mathrm{kg})$. Group IV was grafted with 


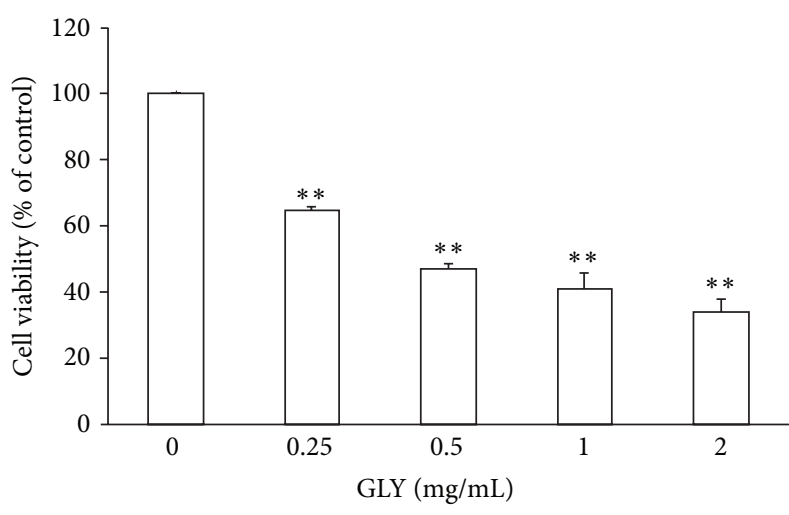

(a)

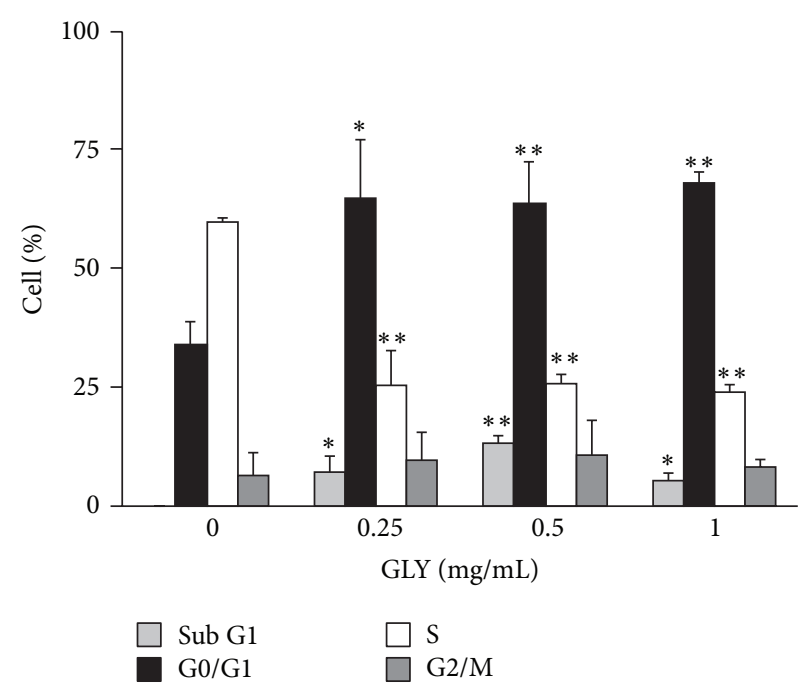

(b)

FIGURE 1: GLY affects cell viability and cell cycle distribution in WEHI-3 cells. WEHI-3 cells were incubated with various concentrations $(0.25,0.5,1.0$, and $2.0 \mathrm{mg} / \mathrm{mL})$ of GLY containing $10 \%$ FBS for $24 \mathrm{~h}$ treatment. The percentage of cell viability was calculated according to the values of control group (10\% FBS-treated group) as 100\% (a). The distribution of cells undergoing various phases of the cell cycle was determined in WEHI-3 cells treated with $0.25,0.5$, and $1.0 \mathrm{mg} / \mathrm{mL}$ GLY for $24 \mathrm{~h}$ (b). The percentage of celld of each treatment was presented as the histogram. Histograms of all values are expressed as the mean $\pm \mathrm{SD} .{ }^{*} P<0.05$ and ${ }^{* *} P<0.01$ compared with the control group.

WEHI-3 cells and then treated with GLY (1.5 g/kg). GLY was diluted in DDW and administrated by oral gavages. The mice were treated daily for 2 weeks and then sacrificed. The livers, spleens, and tumors were obtained and weighed individually.

2.12. Histopathology Examination. The examinations were carried out according to our previous study with minor modification [17]. Tissue samples were fixed in 4\% formaldehyde and embedded in paraffin. Each tissue sample was cut into $5 \mu \mathrm{m}$ section and stained with hematoxylin-eosin (H\&E) method. The histological images were photographed under a light microscopy at 400x magnification. All tissues for histopathological examination and identification of the leukemia cancer cells in the tissue section are looked at under a microscope by a pathologist, a doctor who has special training in laboratory diagnosis of cancers.

2.13. Measurement of Liver Index and Spleen Index. The following formulae can be used for the calculation of spleen index and liver index, spleen index = spleen weight $(\mathrm{g}) / \mathrm{body}$ weight $(\mathrm{g}) \times 100$; liver index $=$ liver weight $(\mathrm{g}) /$ body weight $(\mathrm{g}) \times 100$.

2.14. Statistical Analysis. All data are presented as mean \pm SD for triplicate experiments. Statistical significance was evaluated by one-way ANOVA. A value of $P<0.05$ was regarded as being statistically significant.

\section{Results}

3.1. Inhibitory Effect of GLY on Cell Proliferation of WEHI-3. The antiproliferative effect of GLY was analyzed on WEHI3 treated with 10\% FBS to stimulate cell growth. After $24 \mathrm{~h}$ treatment with GLY, the results showed that the growth effect of WEHI-3 proliferation could be markedly attenuated by GLY (Figure 1(a)) in a dose-dependent manner as compared with control group $(0 \mathrm{mg} / \mathrm{mL}, P<0.05 ; n=3)$.

3.2. Effect of GLY Extract on Cell Cycle Distribution of WEHI3. The cell cycle distribution of WEHI-3 was examined by flow cytometry on cells treated with various concentrations $(0.25,0.5$, and $1.0 \mathrm{mg} / \mathrm{mL})$ of GLY for $24 \mathrm{~h}$. Our result indicated that $24 \mathrm{~h}$ treatment of GLY could markedly arrest cell cycle distribution at G0/G1 phase and decrease at $S$ phase (Figure 1(b), $P<0.05 ; n=3$ ) as compared to those of control group $(0 \mathrm{mg} / \mathrm{mL}$, PBS treated only). The cell population at G0/G1 phase was increased from 33 to $67 \%$ by GLY treatment.

3.3. GLY Induces Monocytic Differentiation in WEHI-3 Cells. NBT-reducing activity, the typical markers of myelomonocytic differentiation, was examined. Our data showed that $48 \mathrm{~h}$ of GLY treatment induced NBT positive cell expression as demonstrated by the presence of intracellular purple formazan deposit (Figure 2). WEHI-3 cells were differentiated by GLY in a dose-dependent manner. Incubation of the cells with $0.125-0.25 \mathrm{mg} / \mathrm{mL}$ of GLY for $48 \mathrm{~h}$ increased the cell differentiation by $32-45 \%$ compared to those of control group (0 mg/mL, PBS treated only), respectively.

3.4. Inhibitory Effect of GLY Extract on Cell Migration of WEHI-3. Migration assays were performed using transwell assay. The antimigratory effect of GLY was analyzed on WEHI-3 cells treated with $10 \%$ FBS to stimulate cell migration. After $4 \mathrm{~h}$ treatment of GLY, 10\% FBS stimulation could largely increase cell migration of WEHI-3, and this migratory effect could be markedly attenuated by GLY treatment (Figures 3(b), 3(c), and 3(d)). In the present study, GLY was found 


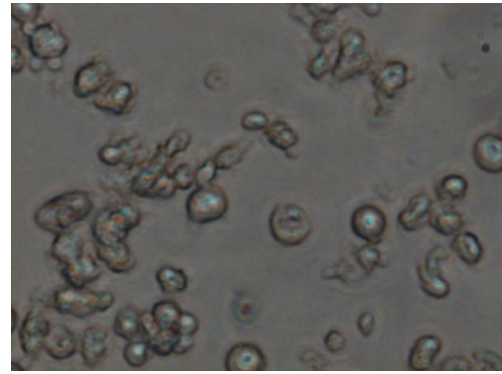

(a)

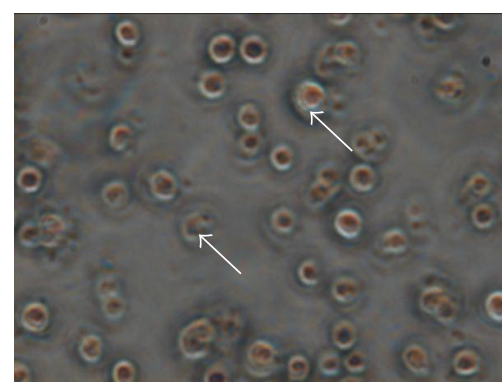

(b)

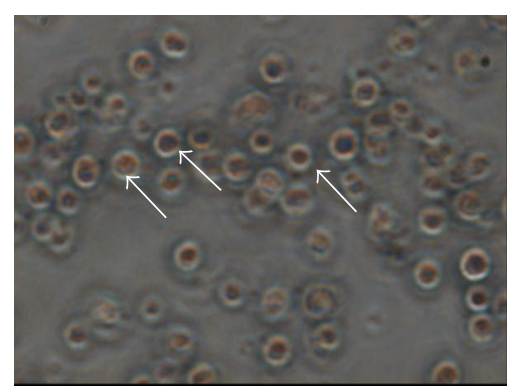

(c)

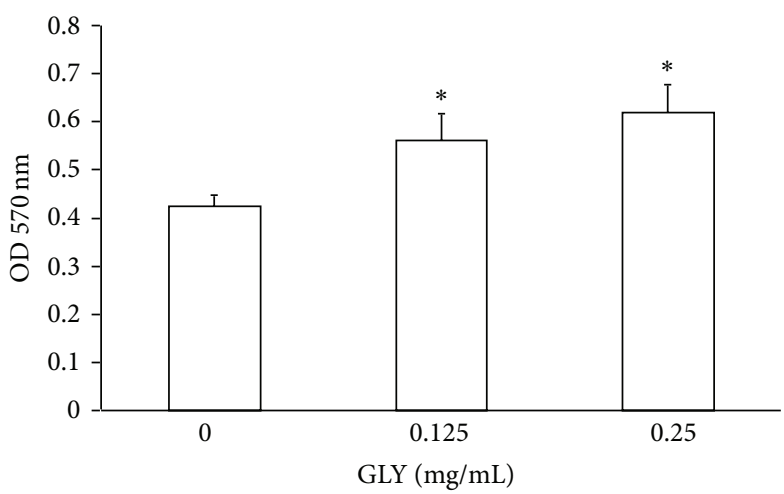

(d)

FIgURE 2: GLY induces differentiation in WEHI-3 cells. WEHI-3 cells were treated with $0,0.125$, and $0.25 \mathrm{mg} / \mathrm{mL}$ GLY for $48 \mathrm{~h}$ and then examined by NBT reduction assay showed insoluble and visible purple formazan precipitates in GLY-treated WEHI-3 cells ((a) 0 mg/mL GLY; (b) $0.125 \mathrm{mg} / \mathrm{mL}$ GLY; (c) $0.25 \mathrm{mg} / \mathrm{mL}$ GLY). The pictures were taken under a microscope at 400x magnification. The OD. $570 \mathrm{~nm}$ of each treatment was presented as the histogram. All values are expressed as the mean \pm SD. ${ }^{*}$ indicates $P<0.05$ as compared with control group $(0 \mathrm{mg} / \mathrm{mL})(\rightarrow$ : NBT-positive cells).

TABLE 2: Antitumor effect of GLY in murine WEHI-3 leukemia model.

\begin{tabular}{lcccc}
\hline Organs & & & Groups & \\
& Normal control & Untreated group & $0.75 \mathrm{~g} / \mathrm{kg} \mathrm{GLY}$ & $0.22 \pm 0.07^{\mathrm{d}}$ \\
\hline Tumor & & $0.57 \pm 0.27$ & $1.48 \pm 0.08^{\mathrm{c}}$ & $0.21 \pm 0.08^{\mathrm{c}}$ \\
Liver & $1.45 \pm 0.08$ & $1.64 \pm 0.06^{\mathrm{a}}$ & $0.14 \pm 0.02$ & $1.47 \pm 0.05^{\mathrm{d}}$ \\
Spleen & $0.09 \pm 0.01$ & $0.14 \pm 0.03^{\mathrm{b}}$ & $0.11 \pm 0.02^{\mathrm{c}}$ \\
\hline
\end{tabular}

Data was presented as grams weight and expressed as the mean $\pm \mathrm{SD}(n=7)$. GLY extract was orally administered one time daily for 14 days. Results: ${ }^{\mathrm{a}} P<0.05$ versus normal control (without tumor graft), ${ }^{\mathrm{b}} P<0.01$ versus normal control, ${ }^{\mathrm{c}} P<0.05$ versus untreated group (tumor graft alone), and ${ }^{\mathrm{d}} P<0.01$ versus untreated group.

to inhibit WEHI-3 migration in a dose-dependent manner as compared with control group (Figure 3(e), $P<0.05$; $n=3)$.

3.5. GLY Decreased Gelatinase Activity in WEHI-3 Cells. To investigate the effect of GLY on gelatinase activity, the WEHI3 cells were treated with $0.25,0.5$, and $1.0 \mathrm{mg} / \mathrm{mL}$ of GLY for $24 \mathrm{~h}$, and the accumulated amount of active MMP-2 and MMP-9 protein in cultured medium of WEHI-3 cells was examined (Figure 4). The result indicated that $1.0 \mathrm{mg} / \mathrm{mL}$ of GLY could markedly decrease the activity expression of MMP-2 and MMP-9 in culture medium as compared with control group (Figure 4, $n=3$ ).

3.6. GLY Inhibited the Expression of Migration- and Cell Cycle-Associated Proteins in Allograft Tumor Samples. We analyzed the protein expression levels of gelatinases and p21 proteins of tumor samples in allograft tumor mice model after 14 days of oral administration of GLY (0.75 and $1.5 \mathrm{~g} / \mathrm{kg})$. Experimental results showed that $1.5 \mathrm{~g} / \mathrm{kg}$ of GLY could significantly reduce the protein levels of MMP-2 and MMP-9 but increase p21 expression as compared with control group (see Supplemental S1 in Supplementary material available online at http://dx.doi.org/10.1155/2013/684071, $n=3$ ).

3.7. Regulation of GLY on Proliferation, Migration and Cell Cycle-Associated Proteins in WEHI-3 Cells. The WEHI-3 cells were treated with $0.25,0.5$, and $1.0 \mathrm{mg} / \mathrm{mL}$ of GLY for $24 \mathrm{~h}$. The results indicated that GLY could markedly decrease pFAK, p-Akt, p-ERK1/2,MMP-2, MMP-9, and p-Rb expression levels but increase $\mathrm{p} 21$ protein expression as compared with control group (Figure 5 and Table $4, n=3$ ). 


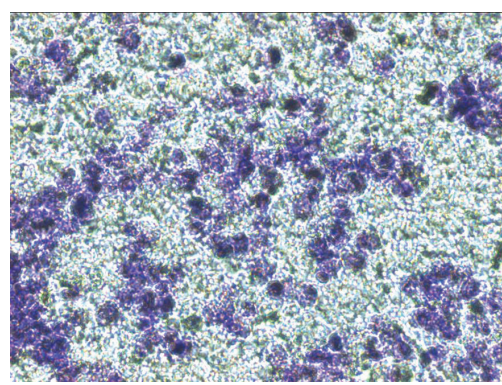

(a)

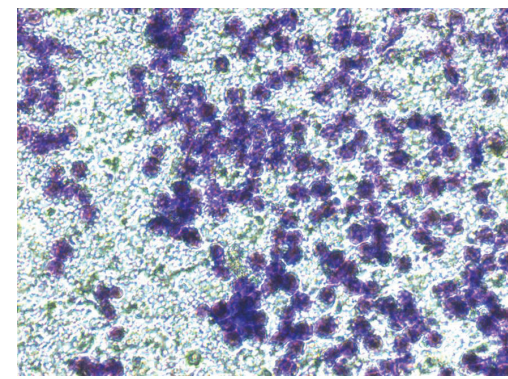

(b)

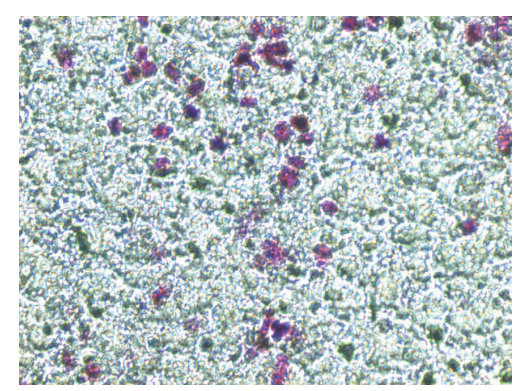

(c)

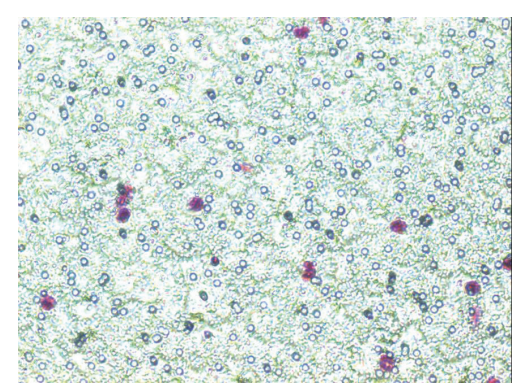

(d)

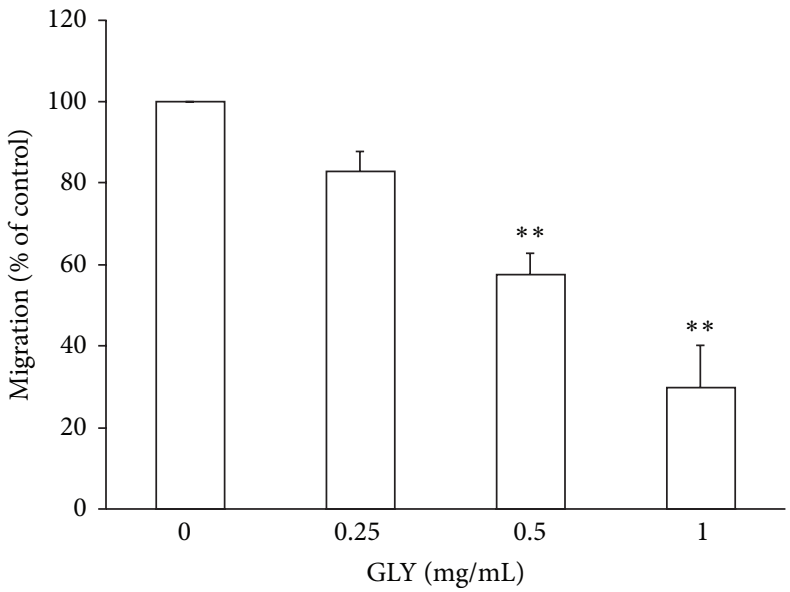

(e)

FIGURE 3: Effect of GLY on WEHI-3 migration was measured by transwell assay. Cells were incubated with various concentrations $(0,0.25$, 0.5 , and $1.0 \mathrm{mg} / \mathrm{mL}$ ) of GLY for $4 \mathrm{~h}$ and were measured by the transwell assay as described in Materials and Methods ((a) $0 \mathrm{mg} / \mathrm{mL}$ group, (b) $0.25 \mathrm{mg} / \mathrm{mL}$ group, (c) $0.5 \mathrm{mg} / \mathrm{mL}$ group, and (d) $1 \mathrm{mg} / \mathrm{mL}$ group). The pictures were taken under a microscope at 200x magnification, and the migrated cells were calculated. ${ }^{*}$ indicates $P<0.05$ as compared with control group $(0 \mathrm{mg} / \mathrm{mL})$. Data are presented as the mean $\pm \mathrm{SD}$ of three separate experiments (e).

TABLE 3: Effect of GLY on ratio of mice organ weight/body weight in murine WEHI-3 leukemia model.

\begin{tabular}{lcccc}
\hline Organs index & \multicolumn{3}{c}{ Groups } & \\
& Normal control & Untreated group & $0.75 \mathrm{~g} / \mathrm{kg} \mathrm{GLY}$ & $1.5 \mathrm{~g} / \mathrm{kg}$ GLY \\
\hline Liver & $5.4 \pm 0.31$ & $7.04 \pm 0.24^{\mathrm{b}}$ & $6.10 \pm 0.47^{\mathrm{b}, \mathrm{d}}$ & $5.86 \pm 0.15^{\mathrm{b}, \mathrm{d}}$ \\
Spleen & $0.33 \pm 0.02$ & $0.58 \pm 0.12^{\mathrm{b}}$ & $0.61 \pm 0.11^{\mathrm{b}}$ & $0.44 \pm 0.07^{\mathrm{a}, \mathrm{d}}$ \\
\hline
\end{tabular}

Data was presented as ratio of mice organ weight/body weight and expressed as the mean \pm SD $(n=7)$. GLY extract was orally administered one time daily for 14 days. Results: ${ }^{\mathrm{a}} \mathrm{P}<0.05$ versus normal control (without tumor graft), ${ }^{\mathrm{b}} \mathrm{P}<0.01$ versus normal control, ${ }^{\mathrm{c}} \mathrm{P}<0.05$ versus untreated group (tumor graft alone), and ${ }^{\mathrm{d}} P<0.01$ versus untreated group.

3.8. Antitumor Effect of GLY in Murine WEHI-3 Leukemia Model. The result showed that 2-week treatment of GLY $(0.75 \mathrm{~g} / \mathrm{kg})$ significantly reduced tumor size by $61 \%$ as compared to untreated group (Table $2, P<0.05$ ). Furthermore, experimental results also showed that GLY $(1.5 \mathrm{~g} / \mathrm{kg})$ was effective at decreasing the leukemic infiltration-induced swelling of liver and spleen by $18.6 \%$ and $21.4 \%$, respectively, as compared to untreated group $(P<0.001)$.

\subsection{Effects of GLY on Leukemic Infiltration-Induced Swelling} of Liver and Spleen in Murine WEHI-3 Leukemia Model. Figure 6(A)-(b) showed that infiltrated WEHI-3 cells were evident in the portal area of liver, resulting in surrounding enlargement of the bile duct and portal vein. In contrast, Figure 6(A)-(d) displayed that $1.5 \mathrm{~g} / \mathrm{kg}$ GLY can improve the phenomenon induced by leukemia infiltration in the portal area of liver. Similarity, the results also showed that leukemia infiltration in the red pulp of spleen was also obviously reduced by GLY treatment (Figure 6(B)-(c) and 6(B)-(d)).

3.10. Influence on the Weight of Immune Organs of Mice. The GLY group showed a decrease in the weight of the spleen and liver in tumor-bearing mice (Table $2, P<0.05$ ), while the untreated group had a significantly higher liver weight and spleen weight (Table 2, $P<0.05$ ). Table 3 shows the values of spleen index and liver index for all experiment groups after 2 weeks of treatment. The spleen index and liver index in GLY $(1.5 \mathrm{~g} / \mathrm{kg})$ were significantly decreased as compared to untreated group $(0.58 \pm 0.12$ versus $0.44 \pm 0.07 ; 7.04 \pm 0.24$ versus $5.86 \pm 0.15)$. 


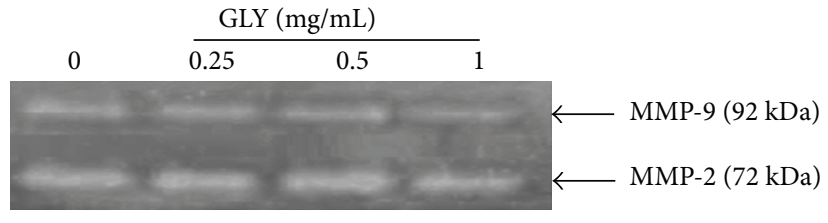

(a)

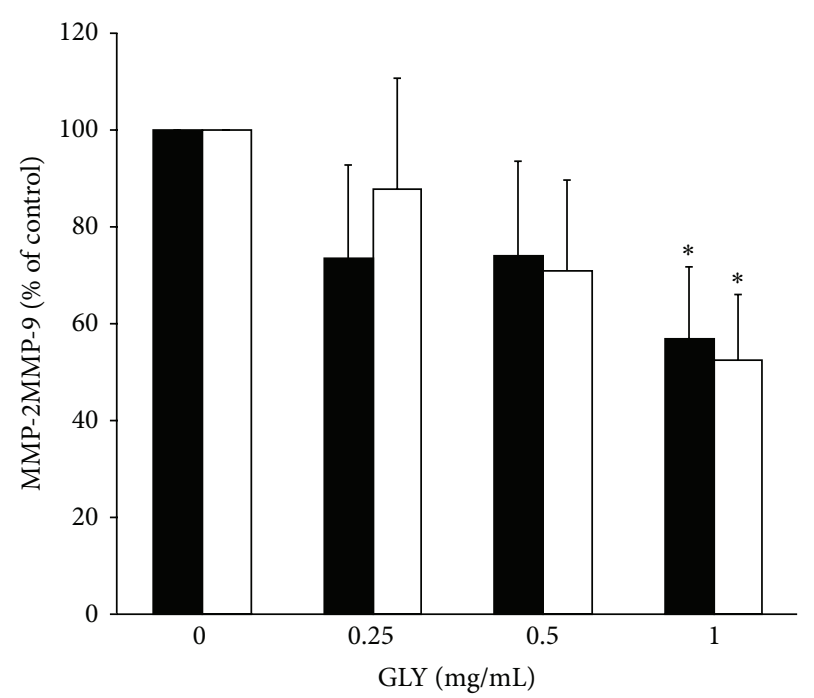

MMP-2

$\square$ MMP-9

(b)

FIGURE 4: Effects of GLY on MMP-2 and MMP-9 activities of WEHI-3 cells. Cells were treated with various concentrations (0.25, 0.5 , and $1.0 \mathrm{mg} / \mathrm{mL}$ ) of GLY for $24 \mathrm{~h}$. MMP-2 and MMP-9 activities were determined by gelatin zymography. The activities of these proteins were subsequently quantified by densitometric analysis. Values (mean $\pm \mathrm{SD}, n=3)$ differ significantly $(P<0.05)($ lower case for MMP-2 and upper case for MMP-9).

TABLE 4: Relative expression level of various proteins in WEHI-3 cells treated with GLY.

\begin{tabular}{lcccc}
\hline Proteins & \multicolumn{3}{c}{ GLY $(\mathrm{mg} / \mathrm{mL})$} \\
& 0 & 0.25 & 0.5 & 1 \\
\hline p-FAK & 1 & $1.12 \pm 0.14$ & $0.65 \pm 0.58$ & $0.30 \pm 0.19^{* *}$ \\
p-Rb & 1 & $0.69 \pm 0.45$ & $0.38 \pm 0.09^{* *}$ & $0.23 \pm 0.09^{* *}$ \\
MMP-9 & 1 & $0.82 \pm 0.34$ & $0.34 \pm 0.10^{* *}$ & $0.24 \pm 0.18^{* *}$ \\
MMP-2 & 1 & $0.87 \pm 0.14$ & $0.66 \pm 0.14^{*}$ & $0.20 \pm 0.17^{* *}$ \\
p-Akt & 1 & $1.13 \pm 0.97$ & $0.71 \pm 0.71$ & $0.24 \pm 0.25^{* *}$ \\
p-ERK1/2 & 1 & $1.07 \pm 0.01$ & $0.41 \pm 0.23^{*}$ & $0.46 \pm 0.33^{*}$ \\
p21 & 1 & $6.00 \pm 4.44$ & $5.273 \pm 2.26^{*}$ & $5.74 \pm 2.67^{*}$ \\
\hline
\end{tabular}

Each value represents the mean \pm SD of triplication. ${ }^{*}$ and ${ }^{* *}$ indicate $P<$ 0.05 and $P<0.01$ as compared with control group (untreated) of each group, respectively.

3.11. Qualification of the Marked Compounds within GLY by Liquid Chromatography/Mass Spectrometry Analysis (LC/ $M S$ ). Some of the index compounds (e.g., naringin, naringenin, and vanillin) from single ingredient within GLY formula were identified by LC/MS to be the index compounds for quality confirmation of extraction procedure for each batch (Figure 7). Our result found that naringin, naringenin, and vanillin could be detected in GLY extract, and the content of naringin, naringenin, and vanillin was calculated to be $13,0.32$, and $0.35 \mathrm{mg} / \mathrm{g}$ of GLY extract, respectively (Table 1).

\section{Discussion}

Recently, Recher et al. mentioned that enhanced expression of FAK in AML promoted cell migration with poor prognosis
[18]. Upregulation of FAK may activate antioxidant enzymes and suppress lipid peroxidation, resulting in antiapoptosis against oxidative stress in human HL-60 cell line [19]. Furthermore, FAK also induced podosome rosettes assembly leading to cell motility and extracellular matrix degradation [20]. On the other hand, the FAK downstream regulator, Akt, also played a critical role in intracellular activation of cell growth and antiapoptosis for cancer survival via mTOR and NRF2 signaling pathway. FAK/PI3 K/Akt was also found to be involved in the regulation of MMP-2 and MMP-9 activities in different cell types $[15,21-23]$. In the present study, we found GLY extract not only decreased p-FAK but also reduced pAkt protein expression in the cell lysate (Figure 5). This effect might explain why GLY extract could significantly affect several biological functions of leukemia cells, including cell proliferation and migration.

Extracellular signal-regulated kinase (ERK) belongs to the family of mitogen-activated protein kinases, which play a critical role in the induction of intracellular activation including proliferation and metastasis in different cancer cells $[24,25]$. In addition, ERK can be constitutively activated in leukemic progenitor cells [26], and inhibition of MEK/ERK signaling leading to apoptosis of AML cells may be a therapeutic remedy in the treatment of leukemia. Moreover, downmodulation of ERK protein kinase activity was found to inhibit VEGF secretion by human myeloma cells as well as myeloma-induced angiogenesis [27, 28]. Furthermore, disruption of retinoblastoma-lamin A complexes and enhanced $\mathrm{Rb}$ phosphorylation by ERK can cause E2F release from Rb-E2F complex and thus promote cell cycle entry and cellular transformation resulting in tumor cell 


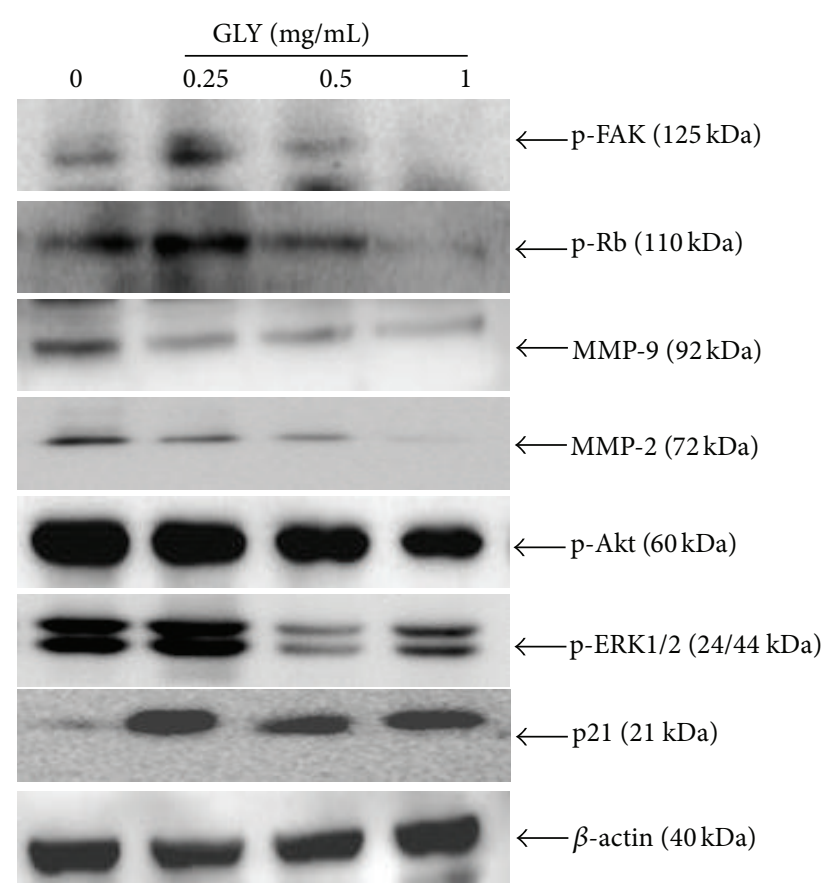

FIGURE 5: Effects of GLY on the phosphorylation of FAK and its downstream targets Akt, ERK1/2, gelatinase of MMP-2, MMP-9, and cell-cycle-related protein Rb and p 21 in WEHI- 3 cells. WEHI3 cells were incubated with several concentrations of GLY for $24 \mathrm{~h}$ to examine the protein expression level of $\mathrm{p}-\mathrm{Rb}, \mathrm{p}-\mathrm{FAK}, \mathrm{MMP}-2$, MMP-9, p-Akt, p-ERK1/2, and p21 proteins. Each value represents the average of three independent experiments in Table 4.

proliferation [29]. Beside, down-regulation of MMP-2 and MMP-9 expression with subsequent decrease in leukemia cancer invasion by caffeine has been attributed to $\mathrm{Ca}^{2+} / \mathrm{ROS}$ mediated suppression of ERK signaling pathway [30]. In the present study, we found that GLY could reduce protein level of $\mathrm{p}-\mathrm{ERK} 1 / 2$ and $\mathrm{p}-\mathrm{Rb}$ expression in cell lysate (Figure 5), suggesting the important role of GLY in cancer progression.

Furthermore, cell cycle advancement also played a critical regulatory mechanism in cell growth. The cell cycle was regulated via $\mathrm{Cdk}$ inhibitors to control cyclin-dependent kinases (Cdks) expression. p21, one of the Cdk inhibitors, was found to regulate the cell cycle progression via interaction with a cyclin-cdk complex to block the kinase activity of Cdk. Activation of p21 by vitamin D3 has been reported to induce myelomonocytic cells differentiation [31]. Cyclin-cdk complexes including cdk 4 and cdk 2 complexes are activated early in the G1 phase. Overexpression of p21 has been known to block the progression of cells from G1 to S phase by counteracting the cdk 4 and cdk 2 complexes. Furthermore, several studies indicated that Akt could stabilize p21 protein via directly phosphorylating $\mathrm{p} 21$, and then increased Cdk activity has been found to stimulate DNA synthesis and cellular proliferation $[32,33]$. p21 can also elicit dephosphorylation of $\mathrm{Rb}$ and inactivates $\mathrm{Rb}$ by degradation in human fibrosarcoma cells [34]. In contrast to phorbol 12-myristate 13-acetate(PMA-) induced leukemia differentiation process, PI3K was found to suppress PMA-induced p21 expression and to reduce cell differentiation of leukemia cells [35]. In the present study, we found that GLY not only increased p21 protein expression in tumor lysate (Supplemental S1) but also increased p21 as well as decreased p-Akt expression in cell lysate (Figure 5).

Leukemia differentiation has also been regarded as an alternative approach for leukemia treatment. ROS (reactive oxygen species) may play an important role in the redifferentiation induced by drugs such as arsenic trioxide. Actually, a relatively high level of ROS is necessary for cell differentiation and animal development [36]. Recently, a study indicated ROS such as $\mathrm{H}_{2} \mathrm{O}_{2}$ can activate NADPH oxidase, leading to $\mathrm{O}_{2}{ }^{\cdot-}$ product, followed by ERK activation and ultimately resulting in the differentiation of HL-60 cells [37]. In this study ROS production was detected by nitroblue tetrazolium (NBT) assay. According to the presence of intracellular purple formazan deposit (Figure 2), our data showed that GLY markedly increase ROS production after $48 \mathrm{~h}$ of treatment. This indicated that GLY-induced differentiation was dependent on ROS production. This further supports previous data obtained in the K562 and HL-60 cell lines with various inducers, including anthracyclines, butyric acid, Ara-C, ADP-Fe ${ }^{2+}, \mathrm{H}_{2} \mathrm{O}_{2}$, and aclarubicin [38]. In the present case of GLY-induced differentiation, ROS generation will probably stimulate specific gene expression through redox sensitive transcription factors (NF- $\kappa$ B, AP-1, NF-E2, etc.). The involvement of these factors has been demonstrated in the erythroid differentiation of K562 cells. Moreover, other bioactive compounds of GLY, such as baicalin and chlorogenic acid, have been reported to increase the ROS generation and then affect different type leukemia cell growth $[39,40]$. The above studies might partially support that GLY could significantly affect WEHI-3 cells on differentiation. As shown in Figure 1(b), WEHI-3 cell population at G0/G1 phase was increased from 33 to $67 \%$ by GLY treatment. These data showed that GLY was able to arrest cell cycle of leukemia cells with subsequent differentiation to macrophage-like cells.

Moreover, MMPs of leukemia cancer cells are the important regulatory factors for cell migration, invasion, and angiogenesis [41, 42]. Feng et al. found that MMP-2 and -9 can increase the permeability of blood-brain barrier by disrupting the tight junction proteins resulting in leukemic cells infiltration to CNS [43]. Therefore, drugs capable of inhibiting leukemia cancer invasion, infiltration, and migration are effective in protecting cancer progression. In the present study, we found that GLY not only attenuated enzyme activities and protein expression level of MMP-2 and MMP-9 in cell lysate, respectively (Figures 4 and 5), but also reduced MMP-2 and MMP-9 protein expression in tumor lysate (Supplemental S1). This finding provided one of the molecular mechanisms why GLY could markedly affect several biological functions of leukemia cells including migration and invasion.

Recently, Lin et al. indicated that GLY was composed of 14 main components via LC/MS and inductively coupled plasma MS (LCP/MS) analysis, including baicalin, baicalein, oroxylin A-7-O-glucuronide, wogonin-7-O-glucuronide, wogonin, and oroxylin A liquiritigenin, liquiritin, glycyrrhizic acid [44]. Our previous study has found baicalein, chlorogenic 


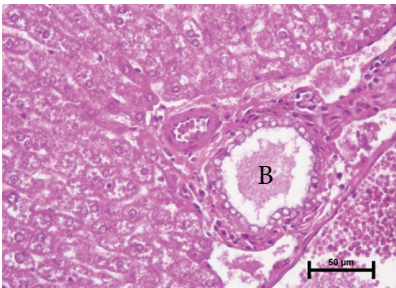

(a)

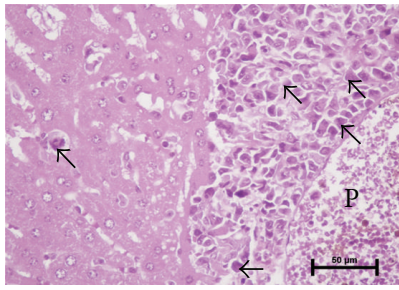

(c)

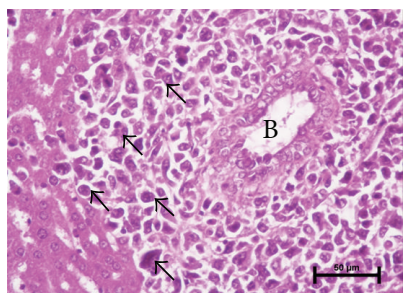

(b)

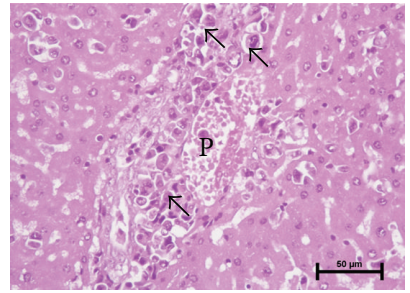

(d)

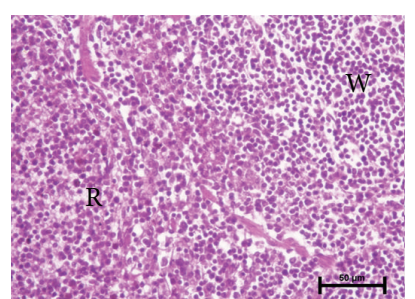

(a)

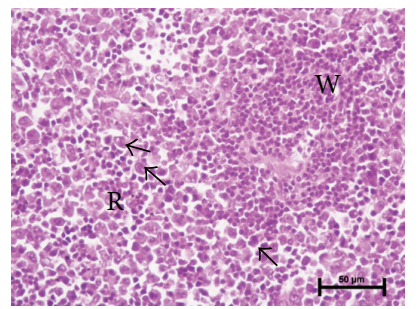

(c)

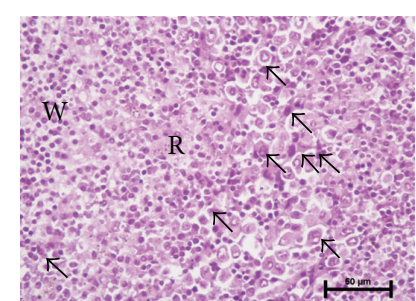

(b)

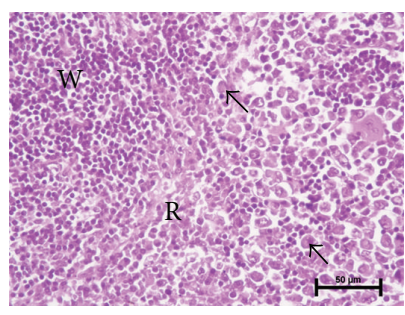

(d)

(A) Liver

(B) Spleen

FIgURE 6: Histopathological examinations of liver and spleen tissues in WEHI-3 allograft tumor model. Tissue sections were stained with hematoxylin-eosin to evaluate the leukemic infiltration. The pictures ((a) normal control group; (b) untreated group; (c) $0.75 \mathrm{~g} / \mathrm{kg}$ GLY group; (d) $1.5 \mathrm{~g} / \mathrm{kg}$ GLY group) were taken under a microscope at 400x magnifications. Arrowheads indicate the infiltrated WEHI-3 leukemic cells within the liver and spleen tissues. W: white pulp of spleen; B: bile duct of liver; R: red pulp of spleen; P: portal vein of liver.

acid, and glycyrrhizic acid as extra components of GLY by LC/MS analysis [9].

Liu et al. reported that baicalin and baicalein, two flavonoids compounds, have inhibitory effects on endothelial cell proliferation, migration, and differentiation [45]. Moreover, it was found that CD11b was highly expressed on myeloid cells when they were differentiated toward either macrophages or granulocytes. Ikezoe et al. indicated that baicalin can induced differentiation of HL-60 cells with overexpression of CD11b [46] and wogonin upregulates phospholipid scramblase 1 gene expression and then induces the granulocytic differentiation of NB4 promyelocytic leukemia cells [47]. Although chlorogenic acid has been known as a caffeic acid-derivative compound, there were no direct lines of evidence to point out its antiangiogenic effect. However, the previous literature indicated that it is a new type and strong matrix metalloproteinase- 9 inhibitor which might prevent the invasion and metastasis of malignant cancer cells $[48,49]$ and chlorogenic acid has inhibitory effects on 4-nitroquinoline-1-oxideinduced tongue carcinogenesis in rats [50]. Recently Cherng et al. reported that glycyrrhizic acid can prevent UVB radiation-induced carcinogenesis in mouse model via inhibiting NF- $\kappa \mathrm{B}$ and cyclooxygenase- 2 and activating p53 and p 21 to prevent DNA damage and facilitate DNA repairing. Glycyrrhizic acid was found to induce prostate cancer cell apoptosis by triggering a caspase-independent apoptotic pathway $[51,52]$. Moreover, numerous studies reported that naringin and wogonin could decrease tumor-induced vascular proliferation by suppressing the release of the VEGF from human tumor cells and inhibiting tumor proliferation and induced cell cycle arrest via p21 activation [53-57]. In addition, naringenin was also reported to could decrease tumors proliferation and growth $[53,54,58,59]$. Several other studies also indicated that vanillin can suppress invasion, metastasis, and angiogenesis through decreasing the enzymatic activity and protein expression level of MMP-9 in cancer cell [60, 61]. The antiangiogenesis effect of vanillin was also found to be associated with PI3K inhibition in human lung cancer cells [62]. In the present study, we have demonstrated naringin, naringenin, and vanillin as the indicator components of GLY (Table 1). This existence of these molecules might partially explain why GLY could significantly affect WEHI-3 cells on cell survival, migration, and differentiation.

We examined the antileukemia effects of GLY by using both in vitro, and in vivo assays. Our results revealed that GLY could markedly inhibit cell viability (Figure 1(a)), induce cell cycle arrest in G0/G1 phase, decrease the cell number in $S$ phase (Figure 1(b)), and reduce cell migration (Figure 3 ). Besides, GLY also decreased the expression level of $\mathrm{p}$-FAK, p-Akt, p-ERK, p-Rb, MMP-2, and MMP-9 whereas increased p21 expression to attenuate leukemia cell growth and migration. Moreover, we also observed that here was a significant decrease in the weight of the tumor, liver, and spleen in the GLY-treated group as compared with control group (Table 2). It was found that GLY administration significantly decreased the spleen index and liver index as compared to the untreated group (Table 3 ). These results suggest that GLY may improve the immunity function in WEHI-3 cancer model mice.

\section{Conclusion}

In conclusion, our investigation demonstrated that GLY has effective inhibitory activities in cell growth and migration of WEHI-3 cancer cells. To the best of our knowledge, this is the first study to explore the inhibitory mechanism of GLY in WEHI-3 cells proliferation and migration with reducing infiltration of leukemia cells into liver and spleens. 


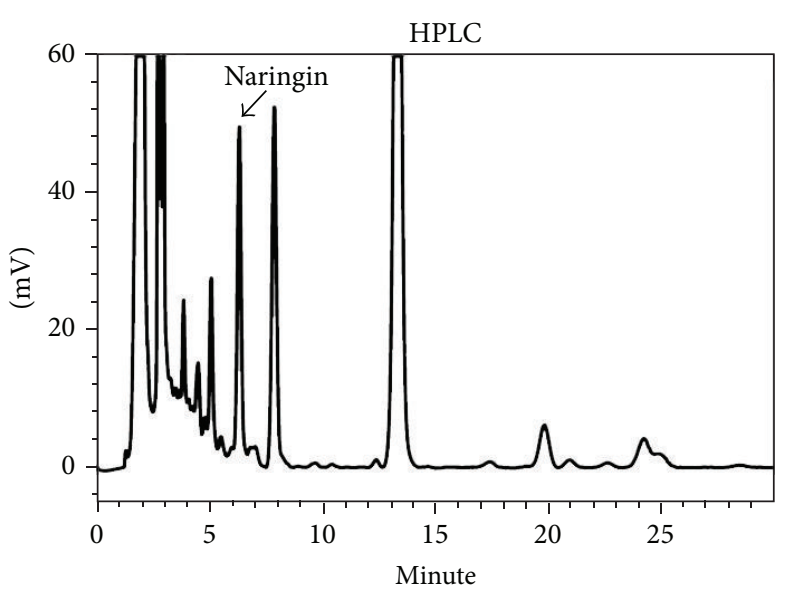

(a) Naringin

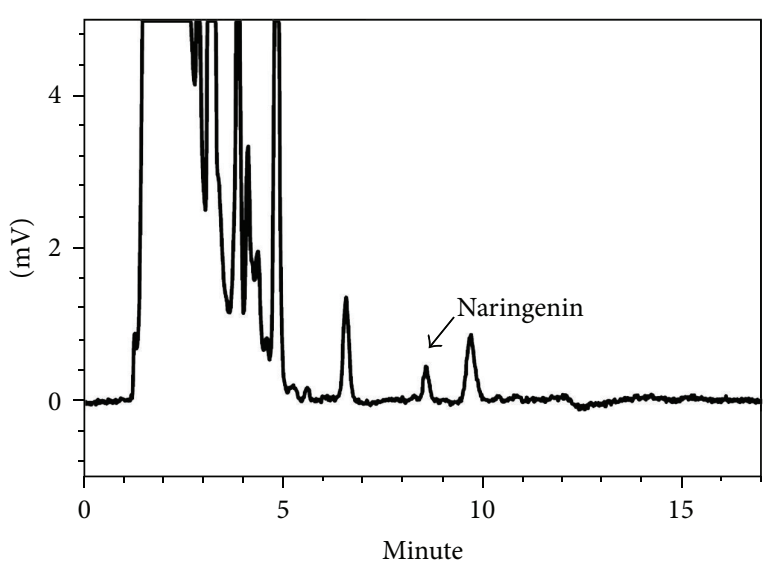

(b) Naringenin

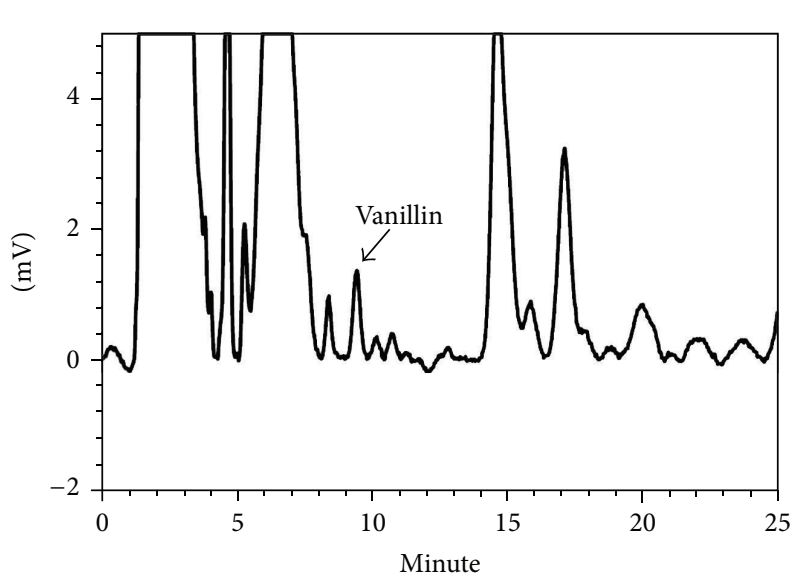

(c) Vanillin
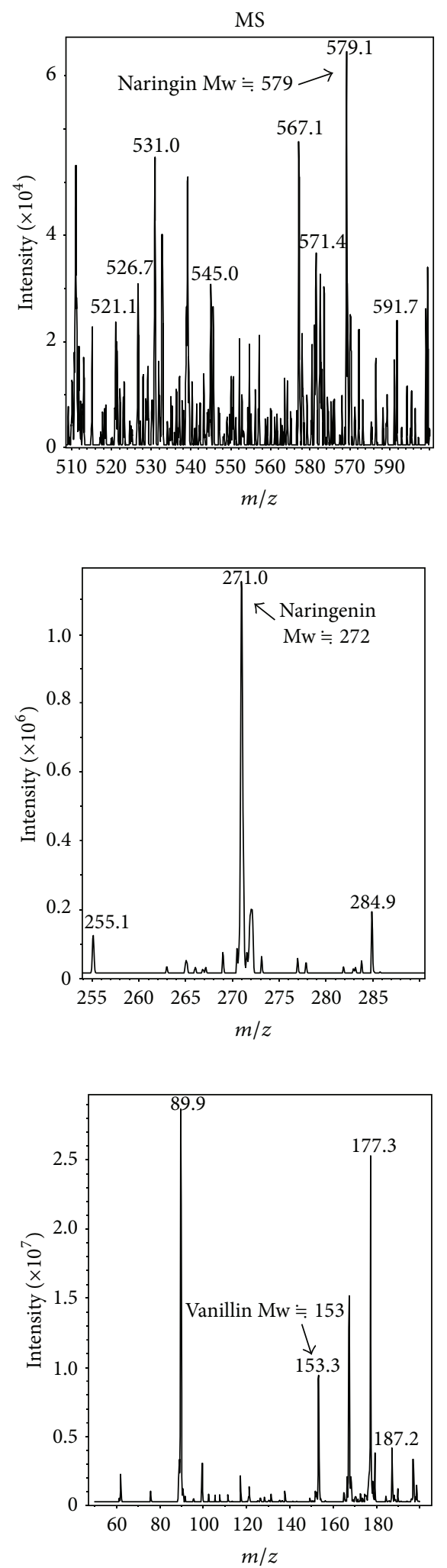

FIGURE 7: Representative HPLC and MS chromatograms of the marked compounds within GLY. The separation conditions were described in the Materials and Methods. The relative content of naringin, naringenin, and vanillin within GLY was measured by HPLC. Three HPLC fractions of GLY were collected according to the retention time of standard compounds to further examine by ESI-MS to confirm molecular size of the suspected compounds, naringin, naringenin, and vanillin. 
According to the previous reports, baicalein, chlorogenic acid, naringin, vanillin, and naringenin in GLY might play an important role to perform the tumor-suppressing effect: firstly, by reducing VEGF expression of tumor cells, such as baicalein [63]; secondary, the inhibitory effects of chlorogenic acid and vanillin on matrix metalloproteinases activity might be another mechanism to prevent cell migration and invasion $[60,61,64]$; thirdly, another component of GLY, naringenin, was found to inhibit cancer cell proliferation [58], making GLY a potential remedy for leukemia therapy. Moreover, WEHI-3 leukemia mice as an animal model were also evident for the antitumor activity of GLY. We found that GLY significantly decreased the average weight of the liver, spleen, and allograft tumor of in BALB/c mice injected with WEHI-3 leukemia cells (Table 2). In addition, the pathological analysis of the liver and spleen section indicated that GLY can reduce the infiltration of WEHI- 3 cells into liver and spleens (Figures 6(A)-(c), 6(A)-(d), 6(B)-(c), and 6(B)-(d)). Based on these results, we proposed that ethanolic extract of GLY can be potential pharmacological reagent in preventing leukemia cancer cell proliferation and migration.

\section{Conflict of Interests}

All authors have reviewed this paper, agreed with its contents, declared that they do not have any conflict of interests on the subject matter or materials in the research, and approved its submission for publication consideration.

\section{Acknowledgments}

Thanks are due to Yu-Hsuan Lin and Miss Wen Hsin Lin, Tai Yun Wu and Pei Hua Tu help for the animal experiment; moreover, thanks are due to Proteomics Research Core Laboratory, Office of Research \& Development, China Medical University, and Miss Wen Hsin Law for ESI-Mass Data Analysis. This work is supported by Grants from the China Medical University and National Science Council (CMU98NCTU-06, NSC97-2320-B-039-013-MY3).

\section{References}

[1] D. Pulte, A. Gondos, and H. Brenner, "Expected long-term survival of patients diagnosed with acute myeloblastic leukemia during 2006-2010," Annals of Oncology, vol. 21, no. 2, pp. 335$341,2010$.

[2] M. Y. Lee, T. D. Tan, and A. C. Feng, "Clinicopathologic analysis of acute myeloid leukemia in a single institution: biphenotypic acute myeloid leukemia may not be an aggressive subtype," Journal of the Chinese Medical Association, vol. 70, no. 7, pp. 269$273,2007$.

[3] S. Amadori, P. Fenaux, H. Ludwig, M. O’Dwyer, and M. Sanz, "Use of arsenic trioxide in haematological malignancies: insight into the clinical development of a novel agent," Current Medical Research and Opinion, vol. 21, no. 3, pp. 403-411, 2005.

[4] A. Glasow, N. Prodromou, K. Xu, M. Von Lindern, and A. Zelent, "Retinoids and myelomonocytic growth factors cooperatively activate RARA and induce human myeloid leukemia cell differentiation via MAP kinase pathways," Blood, vol. 105, no. 1, pp. 341-349, 2005.

[5] J. X. Li, Y. Q. Shen, B. Z. Cai et al., "Arsenic trioxide induces the apoptosis in vascular smooth muscle cells via increasing intracellular calcium and ROS formation," Molecular Biology Reports, vol. 37, no. 3, pp. 1569-1576, 2010.

[6] E. Patatanian and D. F. Thompson, "Retinoic acid syndrome: a review," Journal of Clinical Pharmacy and Therapeutics, vol. 33, no. 4, pp. 331-338, 2008.

[7] A. Gandillet, A. G. Serrano, S. Pearson, M. Lie-A-Ling, G. Lacaud, and V. Kouskoff, "Sox7-sustained expression alters the balance between proliferation and differentiation of hematopoietic progenitors at the onset of blood specification," Blood, vol. 114, no. 23, pp. 4813-4822, 2009.

[8] Y. Y. Cha, E. O. Lee, H. J. Lee et al., "Methylene chloride fraction of Scutellaria barbata induces apoptosis in human U937 leukemia cells via the mitochondrial signaling pathway," Clinica Chimica Acta, vol. 348, no. 1-2, pp. 41-48, 2004.

[9] C. H. Pan, I. C. Hsieh, F. C. Liu et al., "Effects of a Chinese herbal health formula, "gan-Lu-Yin", on angiogenesis," Journal of Agricultural and Food Chemistry, vol. 58, no. 13, pp. 7685-7692, 2010.

[10] J. M. Kim, S. U. Lee, Y. S. Kim, Y. K. Min, and S. H. Kim, "Baicalein stimulates osteoblast differentiation via coordinating activation of MAP kinases and transcription factors," Journal of Cellular Biochemistry, vol. 104, no. 5, pp. 1906-1917, 2008.

[11] P. A. Haridas Nidhina, N. Poulose, and A. Gopalakrishnapillai, "Vanillin induces adipocyte differentiation in 3T3-L1 cells by activating extracellular signal regulated kinase 42/44," Life Sciences, vol. 88, no. 15-16, pp. 675-680, 2011.

[12] T. W. Tan, Y. T. Lin, J. S. Yang et al., “A. cantoniensis inhibits the proliferation of murine leukemia WEHI-3 cells in vivo and promotes immunoresponses in vivo," In Vivo, vol. 23, no. 4, pp. 561566, 2009.

[13] G. Levay and W. J. Bodell, "Potentiation of DNA adduct formation in HL-60 cells by combinations of benzene metabolites," Proceedings of the National Academy of Sciences of the United States of America, vol. 89, no. 15, pp. 7105-7109, 1992.

[14] H. F. Juan, J. W. Hsu, H. C. Huang, S. T. Chen, and C. H. Wong, "Ganoderma lucidum polysaccharides induce macrophage-like differentiation in human leukemia THP-1 cells via caspase and p53 activation," Evidence-Based Complementary and Alternative Medicine, vol. 2011, Article ID 358717, 13 pages, 2011.

[15] Y.-Y. Chen, F.-C. Liu, P.-Y. Chou et al., "Ethanol extracts of fruiting bodies of antrodia cinnamomea suppress CL1-5 human lung adenocarcinoma cells migration by inhibiting matrix metalloproteinase-2/9 through ERK, JNK, p38, and PI3K/Akt signaling pathways," Evidence-Based Complementary and Alternative Medicine, vol. 2012, Article ID 378415, 11 pages, 2012.

[16] H. Li, L. Guo, S. Jie et al., "Berberine inhibits SDF-1-induced AML cells and leukemic stem cells migration via regulation of SDF-1 level in bone marrow stromal cells," Biomedicine and Pharmacotherapy, vol. 62, no. 9, pp. 573-578, 2008.

[17] Y. H. Chang, J. S. Yang, J. L. Yang et al., "Ganoderma lucidum extracts inhibited leukemia WEHI-3 cells in BALB/c mice and promoted an immune response in vivo," Bioscience, Biotechnology and Biochemistry, vol. 73, no. 12, pp. 2589-2594, 2009.

[18] C. Recher, L. Ysebaert, O. Beyne-Rauzy et al., "Expression of focal adhesion kinase in acute myeloid leukemia is associated with enhanced blast migration, increased cellularity, and poor prognosis," Cancer Research, vol. 64, no. 9, pp. 3191-3197, 2004. 
[19] Y. Sonoda, N. Aiba, R. Utsubo, E. Koguchi, M. Hasegawa, and T. Kasahara, "Induction of antioxidant enzymes by FAK in a human leukemic cell line, HL-60," Biochimica et Biophysica Acta, vol. 1683, no. 1-3, pp. 22-32, 2004.

[20] Y.-R. Pan, C.-L. Chen, and H.-C. Chen, "FAK is required for the assembly of podosome rosettes," Journal of Cell Biology, vol. 195, no. 1, pp. 113-129, 2011.

[21] B. T. Hennessy, D. L. Smith, P. T. Ram, Y. Lu, and G. B. Mills, "Exploiting the PI3K/AKT pathway for cancer drug discovery," Nature Reviews Drug Discovery, vol. 4, no. 12, pp. 988-1004, 2005.

[22] J. LoPiccolo, C. A. Granville, J. J. Gills, and P. A. Dennis, "Targeting Akt in cancer therapy," Anti-Cancer Drugs, vol. 18, no. 8, pp. 861-874, 2007.

[23] T. Yamadori, Y. Ishii, S. Homma et al., "Molecular mechanisms for the regulation of Nrf2-mediated cell proliferation in nonsmall-cell lung cancers," Oncogene, vol. 31, no. 45, pp. 47684777, 2012.

[24] J. You, D. Mi, X. Zhou et al., "A positive feedback between activated extracellularly regulated kinase and cyclooxygenase/lipoxygenase maintains proliferation and migration of breast cancer cells," Endocrinology, vol. 150, no. 4, pp. 1607-1616, 2009.

[25] C.-Y. Chiu, K.-K. Kuo, T.-L. Kuo, K.-T. Lee, and K.-H. Cheng, "The activation of MEK/ERK signaling pathway by bone morphogenetic protein 4 to increase hepatocellular carcinoma cell proliferation and migration," Molecular Cancer Research, vol. 10, no. 3, pp. 415-427, 2012.

[26] S. C. Kim, J. S. Hahn, Y. H. Min, N. C. Yoo, Y. W. Ko, and W. J. Lee, "Constitutive activation of extracellular signal-regulated kinase in human acute leukemias: combined role of activation of MEK, hyperexpression of extracellular signal-regulated kinase, and downregulation of a phosphatase, PAC1," Blood, vol. 93, no. 11, pp. 3893-3899, 1999.

[27] N. Giuliani, P. Lunghi, F. Morandi et al., "Downmodulation of ERK protein kinase activity inihibits VEGF secretion by human myeloma cells and myeloma-induced angiogenesis," Leukemia, vol. 18, no. 3, pp. 628-635, 2004.

[28] C. Nishioka, T. Ikezoe, J. Yang, and A. Yokoyama, "Inhibition of MEK/ERK signaling induces apoptosis of acute myelogenous leukemia cells via inhibition of eukaryotic initiation factor $4 \mathrm{E}-$ binding protein 1 and down-regulation of Mcl-1," Apoptosis, vol. 15, no. 7, pp. 795-804, 2010.

[29] J. Rodríguez, F. Calvo, J. M. González, B. Casar, V. Andrés, and P. Crespo, "ERK1/2 MAP kinases promote cell cycle entry by rapid, kinase-independent disruption of retinoblastoma-lamin A complexes," Journal of Cell Biology, vol. 191, no. 5, pp. 967-979, 2010.

[30] W. H. Liu and L. S. Chang, "Caffeine induces matrix metalloproteinase-2 (MMP-2) and MMP-9 down-regulation in human leukemia U937 cells via Ca2+/ROS-mediated suppression of ERK/c-Fos pathway and activation of p38 MAPK/c-Jun pathway," Journal of Cellular Physiology, vol. 224, no. 3, pp. 775-785, 2010.

[31] M. Liu, M. H. Lee, M. Cohen, M. Bommakanti, and L. P. Freedman, "Transcriptional activation of the Cdk inhibitor p21 by vitamin $\mathrm{D}_{3}$ leads to the induced differentiation of the myelomonocytic cell line U937," Genes and Development, vol. 10, no. 2, pp. 142-153, 1996.

[32] F. Chang, J. T. Lee, P. M. Navolanic et al., "Involvement of PI3K/Akt pathway in cell cycle progression, apoptosis, and neoplastic transformation: a target for cancer chemotherapy," Leukemia, vol. 17, no. 3, pp. 590-603, 2003.

[33] Y. Li, D. Dowbenko, and L. A. Lasky, "AKT/PKB phosphorylation of $\mathrm{p} 21^{\mathrm{Cip} / \text { Waf1 }}$ enhances protein stability of $\mathrm{p} 21^{\mathrm{Cip} / \text { Waf } 1}$ and promotes cell survival," The Journal of Biological Chemistry, vol. 277, no. 13, pp. 11352-11361, 2002.

[34] E. V. Broude, M. E. Swift, C. Vivo et al., "p21 ${ }^{\text {Waf1/Cip1/Sid1 }}$ mediates retinoblastoma protein degradation," Oncogene, vol. 26, no. 48, pp. 6954-6958, 2007.

[35] A. Pivoriunas, J. Savickiene, G. Treigyte, V. Tunaitis, R. Navakauskiene, and K. E. Magnusson, "PI 3-K signaling pathway suppresses PMA-induced expression of $\mathrm{p} 21^{\text {Wafl/Cipl } 1}$ in human leukemia cells," Molecular and Cellular Biochemistry, vol. 302, no. 1-2, pp. 9-18, 2007.

[36] H. Chen, B. Zhang, Y. Yao et al., "NADPH oxidase-derived reactive oxygen species are involved in the HL-60 cell monocytic differentiation induced by isoliquiritigenin," Molecules, vol. 17, no. 11, pp. 13424-13438, 2012.

[37] C. Lin and H. Wang, "NADPH oxidase is involved in $\mathrm{H}_{2} \mathrm{O}_{2}$ induced differentiation of human promyelocytic leukaemia HL60 cells," Cell Biology International, vol. 36, no. 4, pp. 391-395, 2012.

[38] D. Richard, H. Morjani, and B. Chénais, "Free radical production and labile iron pool decrease triggered by subtoxic concentration of aclarubicin in human leukemia cell lines," Leukemia Research, vol. 26, no. 10, pp. 927-931, 2002.

[39] H. F. Lu, S. C. Hsueh, Y. T. Ho et al., "ROS mediates baicalininduced apoptosis in human promyelocytic leukemia HL-60 cells through the expression of the Gadd153 and mitochondrialdependent pathway," Anticancer Research, vol. 27, no. 1, pp. 117126, 2007.

[40] E. Burgos-Morón, J. M. Calderón-Montaño, M. L. Orta et al., "The coffee constituent chlorogenic acid induces cellular DNA damage and formation of topoisomerase I- and II-DNA complexes in cells," Journal of Agricultural and Food Chemistry, vol. 60, no. 30, pp. 7384-7391, 2012.

[41] M. Segarra, C. Vilardell, K. Matsumoto et al., "Dual function of focal adhesion kinase in regulating integrin-induced MMP2 and MMP-9 release by human T lymphoid cells," The FASEB Journal, vol. 19, no. 13, pp. 1875-1877, 2005.

[42] J. Paupert, V. Mansat-De Mas, C. Demur, B. Salles, and C. Muller, "Cell-surface MMP-9 regulates the invasive capacity of leukemia blast cells with monocytic features," Cell Cycle, vol. 7, no. 8, pp. 1047-1053, 2008.

[43] S. Feng, J. Cen, Y. Huang et al., "Matrix metalloproteinase-2 and -9 secreted by leukemic cells increase the permeability of bloodbrain barrier by disrupting tight junction proteins," PLOS ONE, vol. 6, no. 8, Article ID e20599, 2011.

[44] I. H. Lin, M. C. Lee, and W. C. Chuang, "Application of LC/MS and ICP/MS for establishing the fingerprint spectrum of the traditional Chinese medicinal preparation Gan-Lu-Yin," Journal of Separation Science, vol. 29, no. 1, pp. 172-179, 2006.

[45] J. J. Liu, T. S. Huang, W. F. Cheng, and F. J. Lu, "Baicalein and baicalin are potent inhibitors of angiogenesis: inhibition of endothelial cell proliferation, migration and differentiation," International Journal of Cancer, vol. 106, no. 4, pp. 559-565, 2003.

[46] T. Ikezoe, S. S. Chen, D. Heber, H. Taguchi, and H. P. Koeffler, "Baicalin is a major component of PC-SPES which inhibits the proliferation of human cancer cells via apoptosis and cell cycle arrest," Journal of Urology, vol. 168, no. 1, pp. 379-380, 2002. 
[47] K. Zhang, Q. L. Guo, Q. D. You et al., "Wogonin induces the granulocytic differentiation of human NB4 promyelocytic leukemia cells and up-regulates phospholipid scramblase 1 gene expression," Cancer Science, vol. 99, no. 4, pp. 689-695, 2008.

[48] U. H. Jin, J. Y. Lee, S. K. Kang et al., "A phenolic compound, 5caffeoylquinic acid (chlorogenic acid), is a new type and strong matrix metalloproteinase- 9 inhibitor: isolation and identification from methanol extract of Euonymus alatus," Life Sciences, vol. 77, no. 22, pp. 2760-2769, 2005.

[49] K. Yagasaki, Y. Miura, R. Okauchi, and T. Furuse, "Inhibitory effects of chlorogenic acid and its related compounds on the invasion of hepatoma cells in culture," Cytotechnology, vol. 33, no. 1-3, pp. 229-235, 2000.

[50] T. Tanaka, T. Kojima, T. Kawamori et al., "Inhibition of 4-nitroquinoline-1-oxide-induced rat tongue carcinogenesis by the naturally occurring plant phenolics caffeic, ellagic, chlorogenic and ferulic acids," Carcinogenesis, vol. 14, no. 7, pp. 1321-1325, 1993.

[51] J. M. Cherng, K. D. Tsai, Y. W. Yu, and J. C. Lin, "Molecular mechanisms underlying chemopreventive activities of glycyrrhizic acid against UVB-radiation-induced carcinogenesis in SKH-1 hairless mouse epidermis," Radiation Research, vol. 176, no. 2, pp. 177-186, 2011.

[52] S. Thiugnanam, L. Xu, K. Ramaswamy, and M. Gnanasekar, "Glycyrrhizin induces apoptosis in prostate cancer cell lines DU-145 and LNCaP," Oncology Reports, vol. 20, no. 6, pp. 13871392, 2008.

[53] A. W. Harmon and Y. M. Patel, "Naringenin inhibits glucose uptake in MCF-7 breast cancer cells: a mechanism for impaired cellular proliferation," Breast Cancer Research and Treatment, vol. 85, no. 2, pp. 103-110, 2004.

[54] S. I. Kanno, A. Tomizawa, T. Hiura et al., "Inhibitory effects of naringenin on tumor growth in human cancer cell lines and sarcoma S-180-implanted mice," Biological and Pharmaceutical Bulletin, vol. 28, no. 3, pp. 527-530, 2005.

[55] H. Luo, B. H. Jiang, S. M. King, and Y. C. Chen, "Inhibition of cell growth and VEGF expression in ovarian cancer cells by flavonoids," Nutrition and Cancer, vol. 60, no. 6, pp. 800-809, 2008.

[56] C. M. Lin, H. Chang, Y. H. Chen, I. H. Wu, and J. H. Chiu, "Wogonin inhibits IL-6-induced angiogenesis via downregulation of VEGF and VEGFR-1, not VEGFR-2," Planta Medica, vol. 72, no. 14, pp. 1305-1310, 2006.

[57] N. Lu, Y. Gao, Y. Ling et al., "Wogonin suppresses tumor growth in vivo and VEGF-induced angiogenesis through inhibiting tyrosine phosphorylation of VEGFR2," Life Sciences, vol. 82, no. 17-18, pp. 956-963, 2008.

[58] H. R. Frydoonfar, D. R. McGrath, and A. D. Spigelman, "The variable effect on proliferation of a colon cancer cell line by the citrus fruit flavonoid Naringenin," Colorectal Disease, vol. 5, no. 2, pp. 149-152, 2003.

[59] G. Ekambaram, P. Rajendran, V. Magesh, and D. Sakthisekaran, "Naringenin reduces tumor size and weight lost in $\mathrm{N}$-methyl$\mathrm{N}^{\prime}$-nitro-N-nitrosoguanidine-induced gastric carcinogenesis in rats," Nutrition Research, vol. 28, no. 2, pp. 106-112, 2008.

[60] K. Lirdprapamongkol, H. Sakurai, N. Kawasaki et al., "Vanillin suppresses in vitro invasion and in vivo metastasis of mouse breast cancer cells," European Journal of Pharmaceutical Sciences, vol. 25, no. 1, pp. 57-65, 2005.

[61] J. A. Liang, S. L. Wu, H. Y. Lo, C. Y. Hsiang, and T. Y. Ho, "Vanillin inhibits matrix metalloproteinase-9 expression through down-regulation of nuclear factor- $\kappa \mathrm{B}$ signaling pathway in human hepatocellular carcinoma cells," Molecular Pharmacology, vol. 75, no. 1, pp. 151-157, 2009.

[62] K. Lirdprapamongkol, J. P. Kramb, T. Suthiphongchai et al., "Vanillin suppresses metastatic potential of human cancer cells through PI3K inhibition and decreases angiogenesis in vivo," Journal of Agricultural and Food Chemistry, vol. 57, no. 8, pp. 3055-3063, 2009.

[63] D. Nie, S. Krishnamoorthy, R. Jin et al., "Mechanisms regulating tumor angiogenesis by 12-lipoxygenase in prostate cancer cells," The Journal of Biological Chemistry, vol. 281, no. 27, pp. 1860118609, 2006.

[64] A. Belkaid, J. C. Currie, J. Desgagnés, and B. Annabi, “The chemopreventive properties of chlorogenic acid reveal a potential new role for the microsomal glucose-6-phosphate translocase in brain tumor progression," Cancer Cell International, vol. 6, article 7, 2006. 


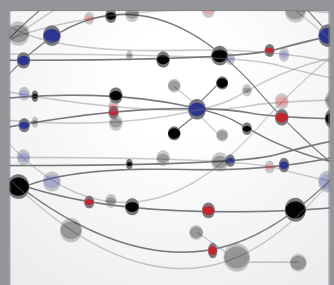

The Scientific World Journal
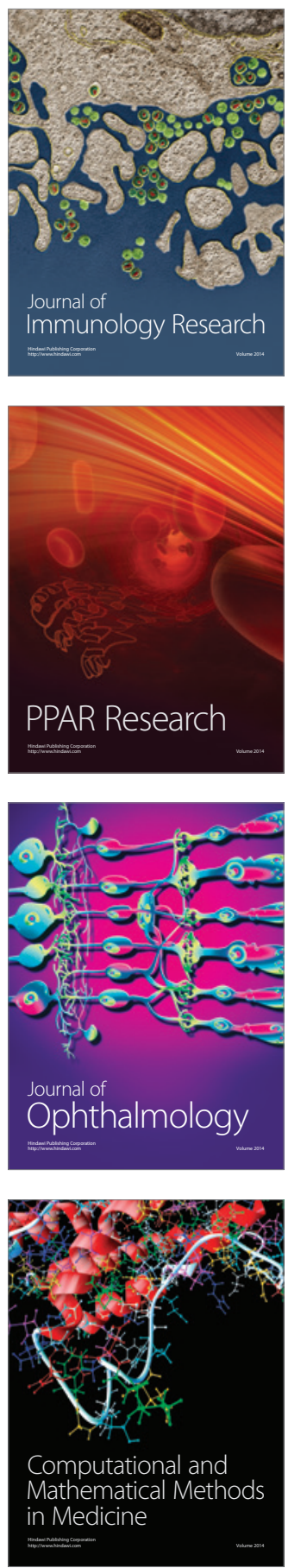

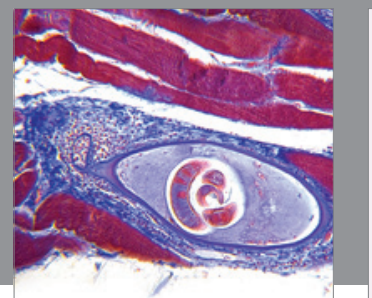

Gastroenterology

Research and Practice
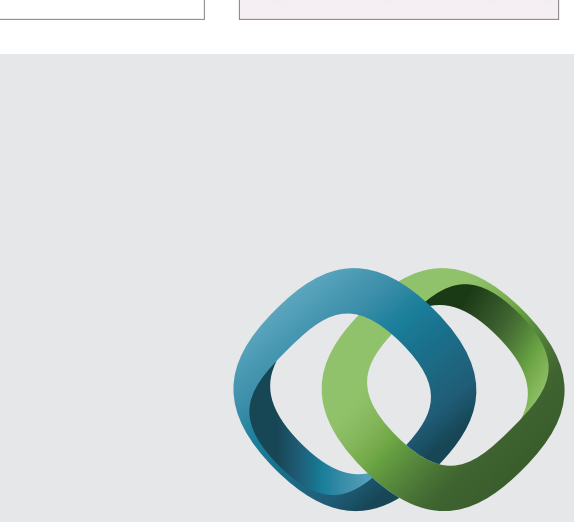

\section{Hindawi}

Submit your manuscripts at

http://www.hindawi.com
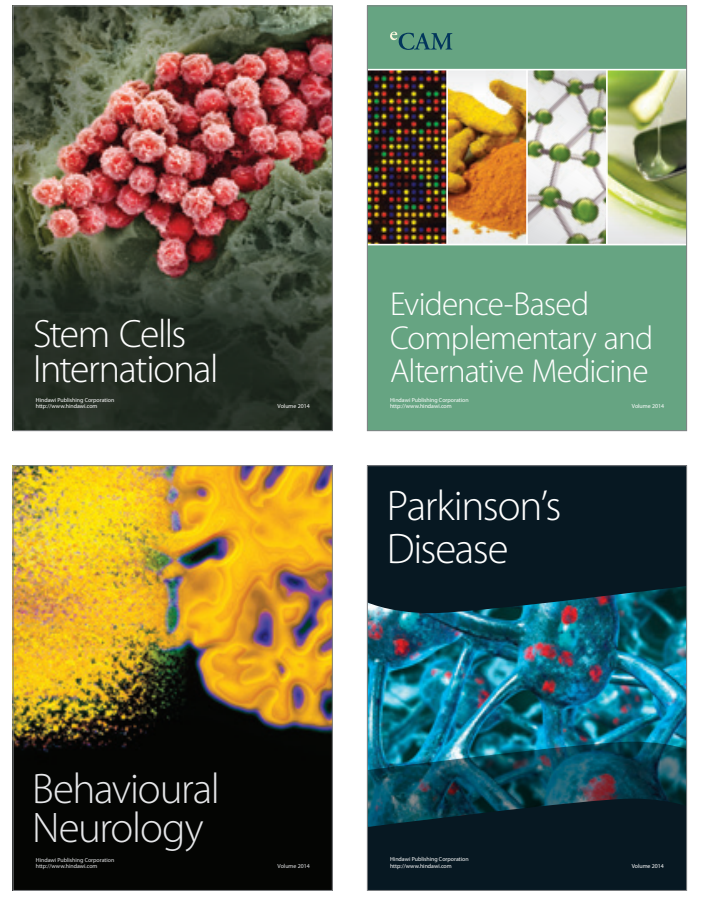
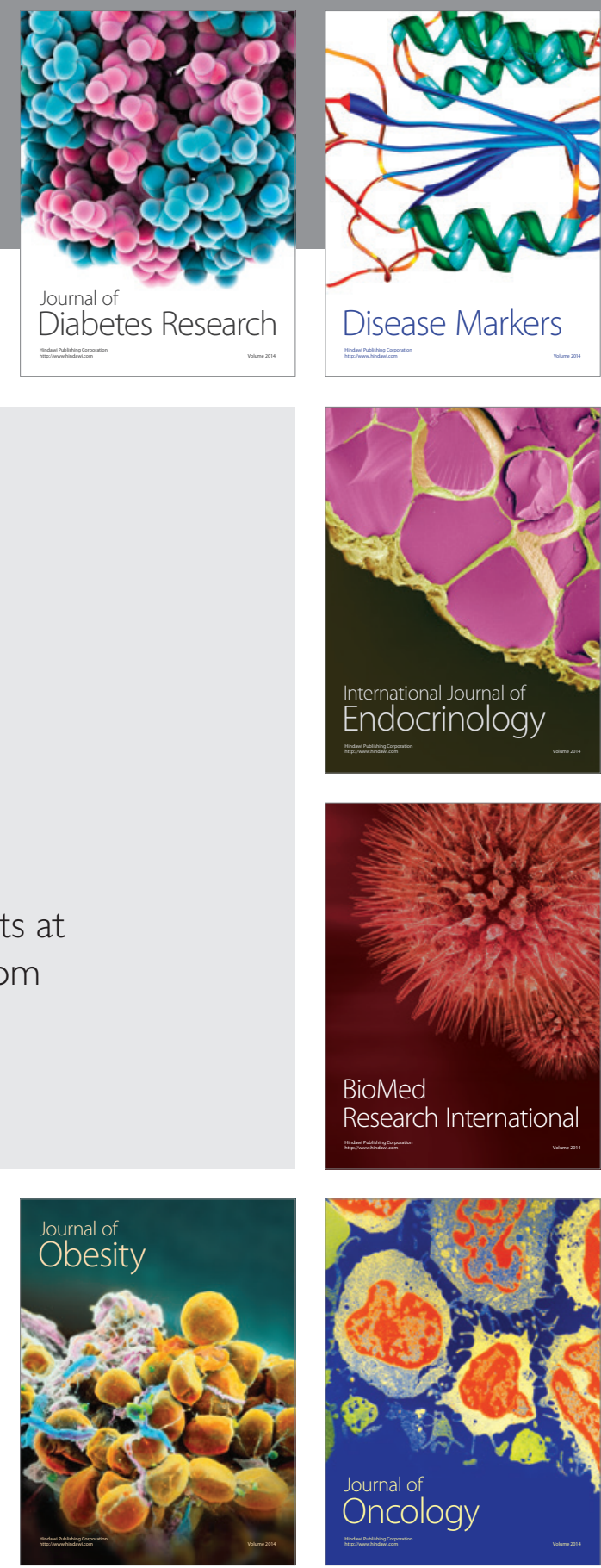

Disease Markers
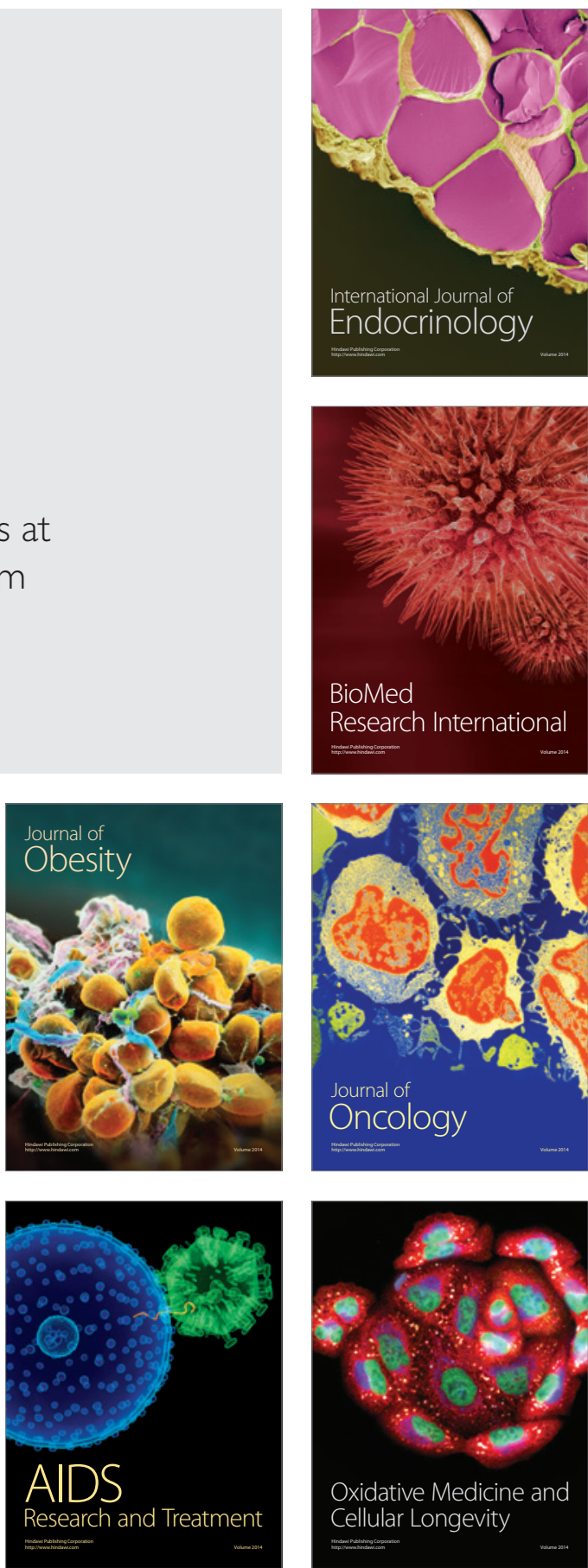